\title{
Implementasi Algoritma K-Nearest Neighbor Untuk Memprediksi Program Studi Bagi Calon Mahasiswa Baru
}

\author{
Ratna Rahmawati Rahayu ${ }^{1 *}$, Lidiawati ${ }^{2}$ \\ 1Program Studi Sistem Informasi, STMIK Bani Saleh \\ 2Program Studi Teknik Informatika, STMIK Bani Saleh \\ *ratnaridw4n@gmail.com
}

\begin{abstract}
Abstrak
Salah satu faktor mahasiswa lulus tepat waktu dengan nilai yang baik adalah karenanya program studi yang diambilnya sesuai dengan minat dan kompetensi. Untuk itu dalam proses penerimaan mahasiswa baru perlu dilakuan seleksi, informasi dan arahan mengenai program studi yang dipilih. Dengan menggunakan data mahasiswa tahun sebelumnya dilakukan pengolahan data mining untuk menghasilkan klasifikasi program studi bagi calon mahasiswa baru. Untuk mendapatkan hasil yang maksimal maka dilakukan data preprocessing, setelahnya data dibagi menjadi data training dan data testing. Kedua data tersebut selanjutnya diolah dengan algoritma K-Nearest Neighbor untuk menentukan kesesuaian class Program Studi yang ada di data testing lalu dihitung nilai akurasi pengukurannya. Karena memiliki nilai akurasi tinggi yaitu $74 \%$, maka dengan menggunakan data training tersebut dikembangkan dalam bentuk aplikasi dengan Java NetBeans yang dapat dipakai untuk membantu calon mahasiswa baru dalam memprediksi program studi yang sesuai.
\end{abstract}

Kata kunci: Data Mining, Klasifikasi, K-Nearest Neighbor, Program Studi

\begin{abstract}
One of the factors for students graduating on time with good grades is that the study program they take is in accordance with their interests and competencies. For this reason, in the process of admitting new students, it is necessary to carry out selection, information and direction regarding the chosen study program. By using previous year's student data, data mining processing is carried out to produce classifications of study programs for prospective new students. To get maximum results, preprocessing data is carried out, after which the data is divided into training data and testing data. The two data are then processed with the K-Nearest Neighbor algorithm to determine the suitability of the Study Program class in the testing data and then the measurement accuracy value is calculated. Because it has a high accuracy value of $74 \%$, using this training data it is developed in the form of an application with Java NetBeans which can be used to assist prospective new students in predicting the appropriate study program.
\end{abstract}

Keywords: Data Mining, Classification, K-Nearest Neighbors, Study Program

\section{Pendahuluan}

Sekolah Tinggi merupakan Perguruan Tinggi yang menyelenggarakan pendidikan akademik dan dapat menyelenggarakan pendidikan vokasi dalam satu rumpun ilmu pengetahuan dan/atau teknologi tertentu. Sedangkan Program Studi merupakan kesatuan kegiatan pendidikan dan Pembelajaran yang memiliki kurikulum dan metode Pembelajaran tertentu dalam satu jenis pendidikan akademik, pendidikan profesi, dan/atau pendidikan vokasi. STMIK Bani Saleh merupakan salah satu perguruan tinggi dengan 
rumpun bidang IImu Komputer dan Manajemen Informatika terdiri dari 5 (lima) program studi, yaitu : Teknik Informatika, Teknik Komputer, Sistem Informasi, Manajemen Informatika dan Komputerisasi Akuntansi. Di dalam deskripsi masing-masing program studi tersebut sudah tertuang kompetensi dan luaran yang dapat dicapai bagi lulusan, sehingga pemilihan program studi bagi calon mahasiswa merupakan hal yang sangat mendasar. Karena mahasiswa akan menuntut ilmu sesuai dengan kompetensi program studi dan dan diharapkan dapat diselesaikan tepat waktu dengan nilai yang baik. Pemilihan program studi yang tidak sesuai dapat menyebabkan seorang mahasiswa berhenti, lulus tidak tepat waktu atau nilai yang kurang bagus.

Pemilihan program studi yang sesuai sangat ditentukan di dalam proses penerimaan mahasiswa baru. Ada beberapa faktor mahasiswa dalam memilihh program studi, diantaranya faktor teman, orang tua atau yang penting kuliah dan lain sebagainya tanpa memperhatikan program studi yang benar-benar sesuai dengan keadaan dirinya. Untuk membantu calon mahasiswa dalam memilih program studi tersebut yang telah dilakukan diantaranya dengan melakukan seleksi wawancara, selain tes seleksi yang terdiri dari pengetahuan umum, matematika dan bahasa Inggris. Berdasarkan hasil tes seleksi tersebut dan riwayat hidup dari calon mahasiswa tersebut, pada saat wawancara dapat diberikan masukan atau pertimbangan antara lain : bagi yang belum atau masih bingung maka dapat diarahkan program studi yang sesuai dengan keadaan dan latar belakangnya, bagi yang sudah memilih tapi dinilai kurang sesuai maka dapat diberi masukan agar tidak salah dalam memilih dan lain sebagainya.

Saat ini sudah di era digital, perkembangan teknologi yang sudah semakin modern, maka untuk memudahkan dalam proses wawancara atau calon mahasiswa dalam memilih program studi dapat dikembangkan sebuah model yang berisikan mengenai pengolahan data yang sudah ada sebelumnya (data training) digunakan untuk mempredikasi, data baru (data testing) merupakan data yang akan diprediksi, kemudian kedua data tersebut diolah dengan menggunakan algoritma K-Nearest Neighbor sehingga dari data testing tersebut akan menghasilkan model untuk memprediksi program studi yang sebaiknya dipilih berdasarkan data yang telah ada sebelumnya.

\section{Tinjauan Pustaka}

\subsection{Penelitan Terkait}

Dalam penelitian ini menggunakan beberapa referensi penelitian, diantaranya :

1. Penelitian yang dilakukan oleh Muhammad Kurniawan Khamdani, Nurul Hidayat dan 
Ratih Kartika Dewi dengan judul "Implementasi Metode K-Nearest Neighbor Untuk Mendiagnosis Penyakit Tanaman Bawang Merah". Dari penelitian tersebut dapat disimpulkan bahwa sumber data penelitian terhadap penyakit bawang merah diperoleh dari Dinas Pertanian Kabupaten Malang. Jenis penyebab penyakit tanaman bawang merah yang dteliti sebanyak 5 (lima) yaitu : ulat bawang, lalat penggorok, moler, trotol dan antrakosa dengan gejala yang dianalisis sebanyak 15 gejala. Setiap gejala memiliki 5 keluaran yaitu : tidak ada gejala, gejala sedikit tapi bukan gejala utama, gejala banyak tapi bukan gejala utama, gejala sedikit dan merupalan gejala utama, dan gejala banyak dan merupakan gejala utama. Berdasarkan data tersebut dilakukan uji coba terhadap 30 data testing dengan $\mathrm{K}=1,4,7$ dan 10 menghasilkan nilai akurasi yang tidak jauh berbeda. Karenanya jumlah $\mathrm{K}$ tidak terlalu mempengaruhi nilai akurasi.

2. Penelitian yang dilakukan oleh Yahya dan Winda Puspita Hidayati yang berjudul "Penerapan Algoritma K-Nearest Neighbor Untuk Klasifikasi Efektivitas Penualan Vape (Rokok Elektrik) pada Lombol Vape On". Yang dapat disimpulkan pada penelitian tersebut adalah dengan menggunakan data hasil penjualan tahun 2019 dilakukan klasifikasi berdasarkan jumlah item atau jenis barang yang mampu terjual dengan klas mencapai target dan tidak mencapai target. Apabila rata-rata jumlah satu jenis barang penjualan 10 pcs dapat disebut sebagai kategori mempu mencapai targer dan apabila kurang dari 10 yang terjual maka akan disebut dengan kategori tidak mampu mencapai target. Pengujian menggunakan nilai $\mathrm{K}=1,2,3,4,5,6,7,8,9$ dan 10 . Semakin tinggi jumlah $\mathrm{K}$ yang digunakan maka akan semakin bagus hasil nilai akurasi.

3. Penelitian yang dilakukan oleh Rio Adi Arnomo, Wawan Laksito Yuly Saptomo dan Paulus Harsadi dengan judul "Implementasi Algoritma K-Nearest Neighbor Untuk Identifikasi Kualitas Air". Yang dapat disimpulkan dari penelitian tersebut adalah penelitian dilakukan berdasarkan laporan uji lab kualitas air bulan Maret dan April 2016 di PDAM kota Surakarta sebanyak 111 data, yang terdiri dari 71 data training dan 40 data testing. Data dikelompokkan dalam 2 (dua) parameter yaitu parameter fisik dengan atribut bau, rasa, suhu, warna dan kekeruhan, dan parameter kimia dengan atribut sisa clor, $\mathrm{pH}$, kesadahan, besi, mangan, ammonium dan nitrit. Dengan variable class yang ditentukan MS (Memenuhi Syarat) dan TMS (Tidak Memenuhi Syarat). Setelah dilakuan pengolahan data dengan algoritma K-NN 
dimana $\mathrm{K}=7$ menghasilkan nilai akurasi sebesar $82,5 \%$.

4. Penelitian yang dilakukan oleh Ni Luh Gede Pivin Suwirmayanti dengan judul "Penerapan Metode K-Nearest Neighbor Untuk Sistem Rekomendasi Pemilihan Mobil". Pada penelitian ini yang dapat disimpulkan berupa perancangan pembuatan model yang terdiri dari data flow diagram, entity relationship diagram, struktur file dan desain sistem. Kriteria-kriteria yang digunakan dalam rekomendasi pemilihan mobil yaitu : tujuan pembelian, harga, tahun pembuatan, kapasitas penumpang, warna, kapasitas mesin, jenis transmisi.

5. Penelitian yang dilakukan oleh Muhammad Rivki dan Adam Mukharil Bachtiar yang berjudul "Implementasi Algoritma K-Narest Neighbor Dalam Pengklasifikasian Follower Twitter Yang Menggunakan Bahasa Indonesia". Yang dapat disimpulkan dari penelitian tersebut adalah bahwa data penelitian diperoleh dengan memanfaatkan REST-ful APIs yang sudah disediakan oleh twitter dan dapat digunakan secara publik. Kemudian dilakukan preprocessing, dan pembobotan. Selanjutnya dilakuan klasifikasi menggunakan algoritma K-Nearest Neighbor dengan nilai $\mathrm{K}=3$, dan class terdiri dari kuliner, travel dan olahraga. Setelah dilakukan 4 (empat) kali pengujian dengan data uji 25, 50, 75 dan 100, diperoleh nilai akurasi terbesar adalah $68 \%$.

\subsection{Landasan Teori}

\section{Data Mining}

Data mining merupakan suatu istilah yang digunakan untuk menguraikan penemuan pengetahuan di dalam database. Data mining adalah proses yang menggunakan teknik statistik, matematika, kecerdasan buatan, dan machine learning untuk mengekstraksi dan mengidentifikasi informasi yang bermanfaat dan pengetahuan yang terkait dari berbagai database yang berukuran besar. Data mining dibagi menjadi beberapa kelompok, yaitu : deskripsi, estimasi, prediksi, klasifikasi, pengklusteran dan asosiasi.

Untuk pengolahan data mining terbagi dalam beberapa tahapan, yaitu :

- Data Cleaning, untuk menghilangkan noise atau yang tidak relevan.

- Data Integration, menggabungkan beberapa sumber data.

- Data Selection, mengambil data yang relevan untuk dianalisis.

- Data Transformation, mengubah data kedalam bentuk yang sesuai dengan model yang digunakan.

- Data Mining, proses aplikasi dengan suatu metode untuk mengekstrak pola data.

- Pattern Evaluation, mengidentifikasi pola yang benar-benar menarik yang mewakili 
pengetahuan yang didasarkan pada beberapa pengukuran.

- Knowledge Presentation, teknik representasi knowledge yang digunakan untuk menyajikan knowledge kepada pengguna.

\section{Preprocessing}

Sekumpulan data yang ada di dalam penyimpanan data cenderung tidak sempurna dikarenakan beberapa hal, yaitu :

- Incomplete, nilai atribut tidak lengkap, nilai atribut yang seharusnya ada tetapi tidak ada.

- Noisy, mengandung error atau outliers (data yang secara nyata berbeda dengan data-data yang lain)

- Inconsistent, terjadi perbedaan dalam pengkodean dan nilai.

\section{Klasifikasi}

Klasifikasi adalah suatu proses menempatkan suatu objek tertentu dalam set kategori berdasarkan properti objek yang bersangkutan. Sehingga hasil dari klasifikasi ini berupa target variabel kategori (class/label). Klasifikasi merupakan proses pembelajaran secara terbimbing (supervised learning), sehingga untuk melakukan klasifikasi dibutuhkan training set sebagai data pembelajaran, dan setiap sampel dari training set memiliki atribut class/label.

\section{Algoritma K-Nearest Neighbor}

Algoritma K-Nearest Neighbor merupakan metode klasifikasi yang menentukan label (class) dari suatu objek baru berdasarkan mayoritas kedekatan jarak dari kategori yang ada dalam KNeighbors. Salah satu teknik menghitung pengukuran jarak dalam K-Nearest Neigbors adalah Euclidean Distance. Euclidean distance antara titik $X_{1}$ and $X_{2}$ merupakan panjang dari $X_{1}$ $X_{2}$. Segmen dalam koordinat Cartesian, jika $X_{1}=$ $\left(X_{11}, X_{12}, \ldots, \overline{X_{1 n}}\right)$ dan $X_{2}=\left(X_{21}, X_{22}, \ldots, X_{2 n}\right)$ merupakan dua titik dalam Euclidean $n$-space, maka jarak dari $X_{1}$ ke $X_{2}$ dapat dihitung sebagai berikut:

$d(p, q)=\sqrt{\sum_{i=1}^{n}\left(p_{i}-q_{i}\right)^{2}}$

Keterangan

$$
\begin{aligned}
& p \text { : nilai atribut data training } \\
& q \text { : nilai atribut data testing }
\end{aligned}
$$

\section{Pengukuran Akurasi}

Untuk mengukur akurasi hasil pengujian data testing pada metode klasifikasi dapat dihitung dengan :

$$
\text { Akurasi }=\frac{\text { Jumlah klasifikasi benar }}{\text { Total data testing yang diuji }}
$$

\subsection{Tahapan Penelitian}

Tahapan-tahapan yang dilakukan pada penelitian ini adalah :

- Pengumpulan data dengan cara mengambil data yang telah ada di database.

- Preprocessing, melakukan data cleaning dan data transformation. 
- Menngelompokkan data menjadi data training dan data testing.

- Menghitung euclidean distance untuk setiap data testing dengan data training untuk menentukan class Program Studi untuk setiap data testing.

- Membandingkan class Program Studi yang dihasilkan dari algoritma K-NN, dengan class Program Studi yang ada di data testing.

- Menghitung pengukuran tingkat akurasi data testing.

- Mengimplementasikan prediksi program studi bagi calon mahasiswa baru dalam bentuk perangkat lunak.

\section{Metode Penelitian}

Pada penelitian ini, data diambil dari data mahasiswa tahun masuk 2019 yang berjumlah 379 record, dengan atribut terdiri dari :

- No. Register, merupakan nomor register pendaftaran.

- Asal Sekolah, nama sekolah tingkat SMU/SMK/MA.

- Jurusan, jurusan yang diambil pada saat SMU/SMK/MA.

- Nilai Tes, merupakan grade dari nilai rata-rata hasil tes seleksi umum, matematika dan bahasa Inggris.

Bentuk data penelitian dapat dilihat pada berikut ini :

Tabel 1. Data Mahasiswa Tahun 2019

\begin{tabular}{|c|c|c|c|c|c|}
\hline NO. REGISTER & ASAL SEKOLAH & $\begin{array}{l}\text { NLLA } \\
\text { TES }\end{array}$ & JURUSAN & PROGRAM STUDI & IPK \\
\hline 2019010002 & PGRI RAWALUMBU & c & TKJ & SISTEM INFORMASI & 3,08 \\
\hline 2019010004 & NEGERI 3 BEKASI & B & TEKNIK KOMPUTER DAN JARINGAN & TEKNK INFORMATKA & 3,4 \\
\hline 2019010005 & NEGERI 1 BENDO KAB. MAGETAN & c & MULTMEDIA & TEKNNK INFORMATKA & \\
\hline 2019010008 & TAMAN HARAPAN & c & TEKNIK KENDARAAN RINGAN & TEKNIK INFORMATKA & 1,9 \\
\hline 2019010010 & KARYA GUNA BHAKT12 & & TEKNIK KOMPUTER DAN JARRGAN & TEKNK INFORMATKA & 3,0 \\
\hline 2019010011 & BNAKARYA MANDIRI 2 & c & TEKNIK KOMPUTER DAN JARRGAN & TEKNK INFORMATKA & \\
\hline 2019010012 & BINA KARYA MANDIRI & & TEKNIK KOMPUTER DAN JARINGAN & TEKNK INFORMATKA & \\
\hline 2019010014 & NEGERI 1 ABUNG BARAT & c & PA & TEKNKI INFORMATKA & \\
\hline 2019010015 & TELEKOMUNKASI TELESANDI BEKASI & A & TEKNIK KOMPUTER DAN JARINGAN & TEKNIK INFORMATKA & \\
\hline 2019010016 & TUNAS HARAPAN PLUPUH & c & TEKNIK OTOMOTF & MANAJEMEN INFORMATKA & \\
\hline 2019010017 & PGRI 11 JAKARTA & c & TEKNIK OTOMOTFF & TEKNKK INFORMATKA & 2,29 \\
\hline 2019010019 & GLOBAL PRMA ISLAMIC SCHOOL & c & TEKNIK KOMPUTER DAN JARNGAN & SISTEM NFORMASI & 3,00 \\
\hline 2019010020 & NEGERI 2 CIKARANG BARAT KAB. BEKASI & c & PEMASARAN & SISTEM INFORMASI & 2,4 \\
\hline 2019010023 & YPAA ALFALAH & c & AKUNTANSI & TEKNK INFORMATKA & 2,8 \\
\hline 2019010024 & NEGERI 1 NGLPAR GUNUNGKIDUL & B & AKUNTANSI & KOMPUTERISASI AKUNTANSI & \\
\hline 2019010025 & KARYA GUNA BHAKT11 & c & TEKNIK KENDARAAN RNGAN & SISTEM INFORMASI & 1,13 \\
\hline 2019010027 & NEGERII LURAGUNG & c & MULTMEDAA & TEKNK INFORMATKA & 2,06 \\
\hline 2019010030 & TELEKOMUNKASI TELESANDI BEKASI & c & TEKNIK KOMPUTER DAN JARINGAN & TEKNIK NFORMATKA & \\
\hline 2019010031 & NEGERI 2 KOTA BEKASI & c & TEKNIK ELEKTRONIKA INDUSTRI & SISTEM NFORMASI & 2,61 \\
\hline 2019010032 & BNA PRESTASI & c & TEKNIK KENDARAAN RINGAN & TEKNNK INFORMATKA & 2,87 \\
\hline
\end{tabular}

Kemudian pada data tersebut dilakukan proses cleaning dengan mengabaikan data yang memiliki kriteria :

- Nilai atributnya tidak lengkap, data yang seharusnya ada tetapi tidak ada.

- IPK kurang dari 3.00. Karena untuk yang IPK lebih dari sama dengan 3.00 dapat dipastikan bahwa mahasiswa tersebut dapat mengikuti matakuliah di program studi. Sehingga dapat dinyatakan mahasiswa tersebut dalam memilih program studi sudah sesuai. Karena itu yang digunakan dalam peneliitian ini hanya mahasiswa yang memiliki IPK lebih dari sama dengan 3.00 .

Sehingga dari 379 record yang ada, setelah dilakuan data cleaning menghasilkan data sebanyak 173 record.

Untuk memudahkan penelitian, data diubah dengan kriteria sebagai berikut :

1. Asal Sekolah, dikelompokkan menjadi 
NEGERI dan SWASTA. Untuk Asal Sekolah yang terdapat kata NEGERI maka dikelompokkan dalam kategori NEGERI selain itu SWASTA.

2. Jurusan, dikelompokkan menjadi 6 kategori :

a. Ekonomi, terdiri dari jurusan Akuntansi, Penjualan dan Perbankan.

b. IPA

c. IPS

d. RPL (Rekayasa Perangkat Lunak)

e. Teknik, terdiri dari semua jurusan bidang teknik : Teknik Mesin, Teknik Otomotif, Teknik Elektronika Industri dll, kecuali TKJ.

f. TKJ (Teknik Komputer Jaringan) Hasil data yang telah dikelompokkan dapat dilihat pada tabel 2 .

Tabel 2. Data Hasil Pengelompokkan

\begin{tabular}{|c|c|c|c|c|l|}
\hline NO. REGISTER & $\begin{array}{c}\text { ASAL } \\
\text { SEKOLAH }\end{array}$ & $\begin{array}{c}\text { NILAI } \\
\text { TES }\end{array}$ & JURUSAN & IPK & \multicolumn{1}{|c|}{ PROGRAM STUDI } \\
\hline 2019010002 & SWASTA & C & TKJ & 3,08 & SISTEM INFORMASI \\
\hline 2019010016 & SWASTA & C & TEKNIK & 3,10 & MANAJEMEN INFORMATIKA \\
\hline 2019010040 & SWASTA & C & TKJ & 3,11 & TEKNIK INFORMATIKA \\
\hline 2019010058 & SWASTA & B & TKJ & 3,13 & TEKNIK INFORMATIKA \\
\hline 2019010060 & SWASTA & A & TKJ & 3,68 & TEKNIK INFORMATIKA \\
\hline 2019010072 & SWASTA & C & TKJ & 3,61 & TEKNIK INFORMATIKA \\
\hline 2019010073 & SWASTA & C & TKJ & 3,24 & TEKNIK INFORMATIKA \\
\hline 2019010077 & SWASTA & B & TKJ & 3,71 & TEKNIK INFORMATIKA \\
\hline 2019010079 & SWASTA & C & TKJ & 3,26 & SISTEM INFORMASI \\
\hline 2019010080 & NEGERI & C & IPA & 3,18 & TEKNIK INFORMATIKA \\
\hline 2019010086 & SWASTA & A & TKJ & 2,97 & TEKNIK INFORMATIKA \\
\hline 2019010097 & NEGERI & B & IPA & 3,55 & TEKNIK INFORMATIKA \\
\hline 2019010103 & SWASTA & A & TKJ & 3,55 & TEKNIK KOMPUTER \\
\hline 2019010108 & NEGERI & B & TKJ & 3,47 & TEKNIK INFORMATIKA \\
\hline 2019010114 & SWASTA & A & TKJ & 3,00 & TEKNIK INFORMATIKA \\
\hline
\end{tabular}

Untuk atribut penelitian selanjutnya yang digunakan adalah Asal Sekolah, Nilai Tes, dan Jurusan. Dengan variable target adalah Program
Studi. Sedangkan IPK hanya digunakan sebagai filter bahwa data yang digunakan sebagai data training dan data testing yang memiliki IPK lebih dari sama dengan 3.00.

Pada tahapan preprocessing selanjutnya dilakukan transformation, mengubah data sesuai dengan bentuk model yang digunakan. Untuk itu diberikan nilai pembobotan yang dapat dilihat pada masing-masing tabel di bawah ini.

Tabel 3. Pembobotan Asal Sekolah

\begin{tabular}{|c|c|}
\hline $\begin{array}{c}\text { ASAL } \\
\text { SEKOLAH }\end{array}$ & BOBOT \\
\hline NEGERI & 1 \\
\hline SWASTA & 2 \\
\hline
\end{tabular}

Tabel 4. Pembobotan Nilai Tes

\begin{tabular}{|c|c|}
\hline NILAI TES & BOBOT \\
\hline A & 3 \\
\hline B & 2 \\
\hline C & 1 \\
\hline
\end{tabular}

Tabel 5. Pembobotan Jurusan

\begin{tabular}{|c|c|}
\hline JURUSAN & BOBOT \\
\hline Ekonomi & 1 \\
\hline IPA & 2 \\
\hline IPS & 3 \\
\hline RPL & 4 \\
\hline Teknik & 5 \\
\hline TKJ & 6 \\
\hline
\end{tabular}

Dari 173 data yang ada sebanyak 130 digunakan untuk data training yang dapat dilihat di tabel 6 , Tabel 6. Data Training 


\begin{tabular}{|c|c|c|c|c|c|c|c|}
\hline NO. REGISTER & $\begin{array}{c}\text { ASAL } \\
\text { SEKOLAH }\end{array}$ & $\begin{array}{c}\text { BOBOT } \\
1\end{array}$ & $\begin{array}{c}\text { NILAI } \\
\text { TES }\end{array}$ & $\begin{array}{c}\text { BOBOT } \\
2\end{array}$ & JURUSAN & $\begin{array}{c}\text { BОВОТ } \\
3\end{array}$ & PROGRAM STUDI \\
\hline 2019010002 & SWASTA & 2 & c & 1 & TKJ & 6 & SISTEM INFORMASI \\
\hline 2019010016 & SWASTA & 2 & c & 1 & TEKNIK & 5 & MANAJEMEN INFORMATIKA \\
\hline 2019010040 & SWASTA & 2 & c & 1 & TKJ & 6 & TEKNIK INFORMATIKA \\
\hline 2019010058 & SWASTA & 2 & B & 2 & TKJ & 6 & TEKNIK INFORMATIKA \\
\hline 2019010060 & SWASTA & 2 & A & 3 & TKJ & 6 & TEKNIK INFORMATIKA \\
\hline 2019010072 & SWASTA & 2 & c & 1 & TKJ & 6 & TEKNIK INFORMATIKA \\
\hline 2019010073 & SWASTA & 2 & c & 1 & TKJ & 6 & TEKNIK INFORMATIKA \\
\hline 2019010077 & SWASTA & 2 & B & 2 & TKJ & 6 & TEKNIK INFORMATIKA \\
\hline 2019010079 & SWASTA & 2 & c & 1 & TKJ & 6 & SISTEM INFORMASI \\
\hline 2019010080 & NEGERI & 1 & c & 1 & $\mathbb{P A}$ & 2 & TEKNIK INFORMATIKA \\
\hline 2019010086 & SWASTA & 2 & A & 3 & TKJ & 6 & TEKNIK INFORMATIKA \\
\hline 2019010097 & NEGERI & 1 & B & 2 & $\mathbb{P A}$ & 2 & TEKNIK INFORMATIKA \\
\hline 2019010103 & SWASTA & 2 & A & 3 & TKJ & 6 & TEKNIK KOMPUTER \\
\hline 2019010108 & NEGERI & 1 & B & 2 & TKJ & 6 & TEKNIK INFORMATIKA \\
\hline 2019010114 & SWASTA & 2 & A & 3 & TKJ & 6 & TEKNIK INFORMATIKA \\
\hline
\end{tabular}

dan sisanya sebanyak 43 digunakan untuk data testing dapat dilihat di tabel 6 .

Tabel 7. Data Testing

\begin{tabular}{|c|c|c|c|c|c|l|}
\hline NO. REGISTER & $\begin{array}{c}\text { ASAL } \\
\text { SEKOLAH }\end{array}$ & $\begin{array}{c}\text { BOBOT } \\
1\end{array}$ & NILAI TES & $\begin{array}{c}\text { BOBOT } \\
2\end{array}$ & JURUSAN & \multicolumn{1}{|c|}{ PROGRAM STUDI } \\
\hline 2019010004 & NEGERI & 1 & B & 2 & TKJ & TEKNIK INFORMATIKA \\
\hline 2019010015 & SWASTA & 2 & A & 3 & TKJ & TEKNIK INFORMATIKA \\
\hline 2019010019 & SWASTA & 2 & $\mathrm{C}$ & 1 & TKJ & SISTEM INFORMASI \\
\hline 2019010035 & SWASTA & 2 & $\mathrm{C}$ & 1 & TKJ & TEKNIK INFORMATIKA \\
\hline 2019010045 & SWASTA & 2 & $\mathrm{~B}$ & 2 & TKJ & TEKNIK KOMPUTER \\
\hline 2019010048 & NEGERI & 1 & $\mathrm{C}$ & 1 & TEKNIK & TEKNIK INFORMATIKA \\
\hline 2019010051 & SWASTA & 2 & $\mathrm{~B}$ & 2 & TKJ & TEKNIK INFORMATIKA \\
\hline 2019010053 & NEGERI & 1 & $\mathrm{C}$ & 1 & IPA & TEKNIK INFORMATIKA \\
\hline 2019010054 & SWASTA & 2 & $\mathrm{C}$ & 1 & TEKNIK & TEKNIK INFORMATIKA \\
\hline 2019010067 & SWASTA & 2 & $\mathrm{C}$ & 1 & TEKNIK & TEKNIK KOMPUTER \\
\hline
\end{tabular}

Kemudian dari masing-masing data training dan data testing diolah menggunakan algoritma KNearest Neighbor dengan $K=7$, dan dihitung nilai akurasinya.

\section{Hasil dan Pembahasan}

Pada penelitian ini perhitungan masih dilakukan dengan menggunakan Ms. Excel. Hal ini dilakukan agar peneliti lebih memahami proses perhitungan tersebut agar lebih mudah dalam pembuatan aplikasinya.
Perhitungan mencari jarak antara data data testing ke-1 dengan data training ke-1 dengan cara :

$$
\begin{aligned}
d(p, q)= & \sqrt{(2-1)^{2}+(1-2)^{2}+(6-6)^{2}} \\
= & \sqrt{2}=1,41
\end{aligned}
$$

Kemudian dihitung data testing-1 dengan data training ke-2 sampai data training ke-130, diperoleh hasil secara keseluruhan ditunjukkan pada tabel 8.

Tabel 8. Jarak data testing ke-1 dengan seluruhdata training

\begin{tabular}{|c|c|c|c|l|c|}
\hline NO. REGISTER & $\begin{array}{c}\text { BOBOT } \\
\mathbf{1}\end{array}$ & $\begin{array}{c}\text { BOBOT } \\
\mathbf{2}\end{array}$ & $\begin{array}{c}\text { BOBOT } \\
\mathbf{3}\end{array}$ & \multicolumn{1}{|c|}{ PROGRAM STUDI } & JARAK \\
\hline 2019010002 & 2 & 1 & 6 & SISTEM INFORMASI & 1,41 \\
\hline 2019010016 & 2 & 1 & 5 & MANAJEMEN INFORMATIKA & 1,73 \\
\hline 2019010040 & 2 & 1 & 6 & TEKNIK INFORMATIKA & 1,41 \\
\hline 2019010058 & 2 & 2 & 6 & TEKNIK INFORMATIKA & 1,00 \\
\hline 2019010060 & 2 & 3 & 6 & TEKNIK INFORMATIKA & 1,41 \\
\hline 2019010072 & 2 & 1 & 6 & TEKNIK INFORMATIKA & 1,41 \\
\hline 2019010073 & 2 & 1 & 6 & TEKNIK INFORMATIKA & 1,41 \\
\hline 2019010077 & 2 & 2 & 6 & TEKNIK INFORMATIKA & 1,00 \\
\hline 2019010079 & 2 & 1 & 6 & SISTEM INFORMASI & 1,41 \\
\hline 2019010080 & 1 & 1 & 2 & TEKNIK INFORMATIKA & 4,12 \\
\hline 2019010086 & 2 & 3 & 6 & TEKNIK INFORMATIKA & 1,41 \\
\hline 2019010097 & 1 & 2 & 2 & TEKNIK INFORMATIKA & 4,00 \\
\hline 2019010103 & 2 & 3 & 6 & TEKNIK KOMPUTER & 1,41 \\
\hline 2019010108 & 1 & 2 & 6 & TEKNIK INFORMATIKA & 0,00 \\
\hline 2019010114 & 2 & 3 & 6 & TEKNIK INFORMATIKA & 1,41 \\
\hline
\end{tabular}

Data diurutkan secara ascending berdasarkan jarak. Karena ditentukan $\mathrm{K}=7$ maka untuk 7 (tujuh) tetangga terdekat adalah data kesatu sampai ketujuh seperti yang telihat pada tabel 10.

Tabel 10. Penentuan jarak terdekat dan class 


\begin{tabular}{|c|c|c|c|l|c|}
\hline NO. REGISTER & $\begin{array}{c}\text { BOBOT } \\
\mathbf{1}\end{array}$ & $\begin{array}{c}\text { BOBOT } \\
\mathbf{2}\end{array}$ & $\begin{array}{c}\text { BOBOT } \\
\mathbf{3}\end{array}$ & \multicolumn{1}{|c|}{ PROGRAM STUDI } & JARAK \\
\hline $\mathbf{2 0 1 9 0 1 0 1 0 8}$ & $\mathbf{1}$ & $\mathbf{2}$ & $\mathbf{6}$ & TEKNIK INFORMATIKA & $\mathbf{0 , 0 0}$ \\
\hline $\mathbf{2 0 1 9 0 1 0 1 3 3}$ & $\mathbf{1}$ & $\mathbf{2}$ & $\mathbf{6}$ & TEKNIK INFORMATIKA & $\mathbf{0 , 0 0}$ \\
\hline $\mathbf{2 0 1 9 0 1 0 3 5 3}$ & $\mathbf{1}$ & $\mathbf{2}$ & $\mathbf{6}$ & TEKNIK INFORMATIKA & $\mathbf{0 , 0 0}$ \\
\hline $\mathbf{2 0 1 9 0 1 0 3 5 3}$ & $\mathbf{1}$ & $\mathbf{2}$ & $\mathbf{6}$ & TEKNIK INFORMATIKA & $\mathbf{0 , 0 0}$ \\
\hline $\mathbf{2 0 1 9 0 1 0 4 1 5}$ & $\mathbf{1}$ & $\mathbf{2}$ & $\mathbf{6}$ & SISTEM INFORMASI & $\mathbf{0 , 0 0}$ \\
\hline $\mathbf{2 0 1 9 0 1 0 0 5 8}$ & $\mathbf{2}$ & $\mathbf{2}$ & $\mathbf{6}$ & TEKNIK INFORMATIKA & $\mathbf{1 , 0 0}$ \\
\hline $\mathbf{2 0 1 9 0 1 0 0 7 7}$ & $\mathbf{2}$ & $\mathbf{2}$ & $\mathbf{6}$ & TEKNIK INFORMATIKA & $\mathbf{1 , 0 0}$ \\
\hline 2019010123 & $\mathbf{1}$ & $\mathbf{3}$ & $\mathbf{6}$ & TEKNIK KOMPUTER & 1,00 \\
\hline 2019010135 & $\mathbf{2}$ & $\mathbf{2}$ & $\mathbf{6}$ & SISTEM INFORMASI & 1,00 \\
\hline 2019010191 & 2 & $\mathbf{2}$ & $\mathbf{6}$ & TEKNIK INFORMATIKA & 1,00 \\
\hline 2019010295 & 1 & 3 & 6 & TEKNIK INFORMATIKA & 1,00 \\
\hline 2019010323 & 2 & 2 & 6 & TEKNIK INFORMATIKA & 1,00 \\
\hline 2019010331 & 2 & 2 & 6 & MANAJEMEN INFORMATIKA & 1,00 \\
\hline 2019010344 & $\mathbf{1}$ & $\mathbf{1}$ & $\mathbf{6}$ & TEKNIK INFORMATIKA & 1,00 \\
\hline 2019010344 & 1 & $\mathbf{1}$ & $\mathbf{6}$ & TEKNIK INFORMATIKA & 1,00 \\
\hline
\end{tabular}

Dari 7 (tujuh) tetangga terdekat tersebut diperoleh class Teknik Informatika sebanyak 6 sedangkan class Sistem Informasi sebanyak 1 seperti yang dapat dilihat pada tabel 10. Karena mayoritas adalah class Teknik Informatika, sehingga dapat disimpulkan untuk data testing calon mahasiswa dengan data Asal Sekolah = Negeri, Nilai Tes $=\mathrm{B}$ dan dari Jurusan $=\mathrm{TKJ}$ maka prediksikan calon mahasiswa tersebut akan memilih Program Studi Teknik Informatika.

Perhitungan untuk mencari class Program Studi dilakukan untuk semua data testing yang hasilnya dapat dilihat pada tabel 11.

Tabel 11. Hasil klasifikasi antara data testing dengan data hasil K-NN

\begin{tabular}{|c|c|c|c|l|l|}
\hline NO. REGISTER & $\begin{array}{c}\text { BOBOT } \\
1\end{array}$ & $\begin{array}{c}\text { BOBOT } \\
2\end{array}$ & $\begin{array}{c}\text { BOBOT } \\
3\end{array}$ & $\begin{array}{c}\text { PROGAM STUDI } \\
\text { (Data Testing) }\end{array}$ & $\begin{array}{c}\text { PROGRAM STUDI } \\
\text { (K-NN; K } 7 \text { ) }\end{array}$ \\
\hline 2019010004 & 1 & 2 & 6 & TEKNIK INFORMATIKA & TEKNIK INFORMATIKA \\
\hline 2019010015 & 2 & 3 & 6 & TEKNIK INFORMATIKA & TEKNIK INFORMATIKA \\
\hline 2019010019 & 2 & 1 & 6 & SISTEM INFORMASI & TEKNIK INFORMATIKA \\
\hline 2019010035 & 2 & 1 & 6 & TEKNIK INFORMATIKA & TEKNIK INFORMATIKA \\
\hline 2019010045 & 2 & 2 & 6 & TEKNIK KOMPUTER & TEKNIK INFORMATIKA \\
\hline 2019010048 & 1 & 1 & 5 & TEKNIK INFORMATIKA & KOMPUTERISASI AKUNTANSI \\
\hline 2019010051 & 2 & 2 & 6 & TEKNIK INFORMATIKA & TEKNIK INFORMATIKA \\
\hline 2019010053 & 1 & 1 & 2 & TEKNIK INFORMATIKA & SISTEM INFORMASI \\
\hline 2019010054 & 2 & 1 & 5 & TEKNIK INFORMATIKA & TEKNIK KOMPUTER \\
\hline 2019010067 & 2 & 1 & 5 & TEKNIK KOMPUTER & TEKNIK KOMPUTER \\
\hline
\end{tabular}

Berdasarkan hasil pada tabel 11 secara keseluruhan diperoleh class Program Studi (Data Testing) yang hasilnya sama dengan class Program Studi (K-NN; K=7) berjumlah 32 data, sehingga diperoleh nilai akurasi sebesar :

$$
\text { Akurasi }=\frac{32}{43}=74 \%
$$

Dari rangkaian proses menentukan class Program Studi dengan algoritma K-NN yang menggunakan pengukuran jarak Euclidean Distance diimplementasikan ke Java NetBeans dengan rancangan seperti pada gambar 1 .

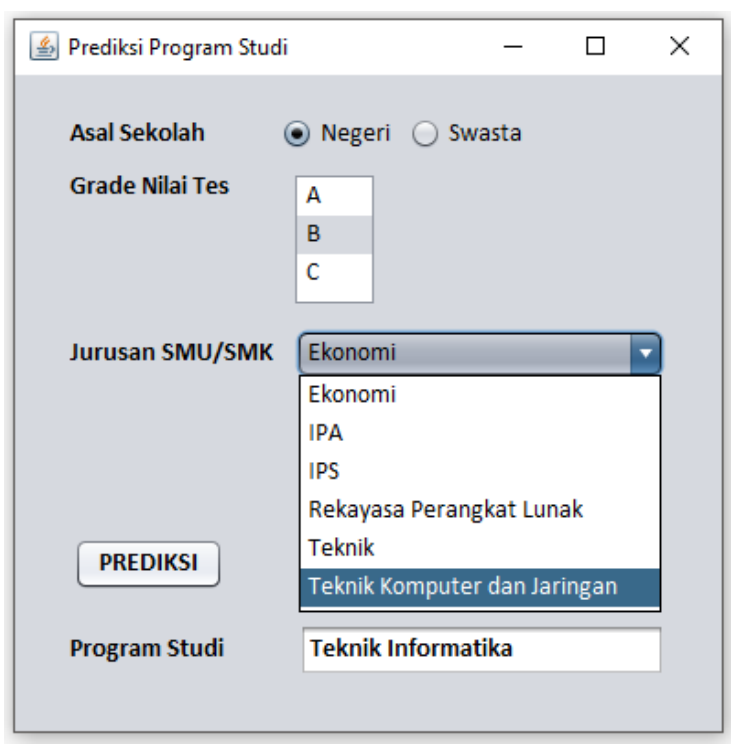

Gambar 1. Rancangan Form

Pada penelitian ini, aplikasi yang dibangun hanya terdiri dari satu form saja, yaitu untuk membantu memprediksi program studi bagi calon mahasiswa baru yang masih bingung dalam menentukan program studi. Sehingga 
rancangan database hanya terdiri satu tabel untuk menyimpan data training. Sedangkan penyimpanan data lainnya menggunakan variable dan array yang didefinisikan dalam program. Pengolahan data algoritma K-NN ada di proses tombol Prediksi yang hasilnya akan ditampilkan pada teks Program Studi. Karena aplikasi ini hanya membantu bagi calon mahasiswa dalam memilih program studi maka data calon mahasiswa tidak disimpan dalam database.

\section{Kesimpulan}

Dari penelitian yang telah dilakukan, maka dapat disimpulkan beberapa hal sebagai berikut :

1. Dalam klasifikasi dengan algoritma K-NN diperlukan data training yang digunakan sebagai data pembelajaran yang diambil dari data mahasiswa tahun masuk 2019 dengan jumlah data yang digunakan sebanyak 173 data.

2. Pengolahan data terhadap 43 data testing dan 130 data training dengan algoritma KNN menggunakan rumus pengukuran jarak Euclidean Distance diperoleh nilai akurasi sebesar $74 \%$.

3. Dengan nilai akurasi yang cukup tinggi maka dengan data training tersebut layak untuk digunakan sebagai data pendukung untuk memprediksi calon mahasiswa baru dalam memilih program studi.

\section{Daftar Pustaka}

[1] A. Q. Sesilia Novita R, Prihastuti Harsani, "Penerapan K-Nearest Neighbor ( KNN ) untuk Klasifikasi Anggrek Berdasarkan Karakter Morfologi Daun dan Bunga," J. IIm. Ilmu Komput. dan Mat., vol. 15, no. 1, pp. 118-125, 2018, [Online]. Available: https://journal.unpak.ac.id/index.php/komput asi/article/view/1267/1074.

[2] A. S. Budiman and X. A. Parandani, "Uji Akurasi Klasifikasi Dan Validasi Data Pada Penggunaan Metode Membership Function Dan Algoritma C4.5 Dalam Penilaian Penerima Beasiswa," Simetris J. Tek. Mesin, Elektro dan IImu Komput., vol. 9, no. 1 , pp. 565-578, 2018, doi: 10.24176/simet.v9i1.2021.

[3] A. Q. Sesilia Novita R, Prihastuti Harsani, "Penerapan K-Nearest Neighbor ( KNN ) untuk Klasifikasi Anggrek Berdasarkan Karakter Morfologi Daun dan Bunga," J. IIm. IImu Komput. dan Mat., vol. 15, no. 1, pp. 118-125, 2018, [Online]. Available: https://journal.unpak.ac.id/index.php/komput asi/article/view/1267/1074.

[4] A. Yobioktabera and A. W. Wibowo, "Penerapan Data Mining Untuk Memprediksi Penerimaan Calon Mahasiswa Baru Fakultas Kedokteran," J. Tek. Elektro Terap., vol. 10, no. 1, pp. 16-19, 2021, [Online]. Available: https://jurnal.polines.ac.id/index.php/jtet/artic le/view/2550/pdf.

[5] Luh Gede Pivin Suwirmayanti, "Penerapan Metode K-Nearest Neighbor Untuk Sistem Rekomendasi Pemilihan Mobil Implementation of K-Nearest Neighbor Method for Car Selection Recommendation System," Techno.COM, vol. 16, no. 2, pp. 120-131, 2017.

[6] M. K. Khamdani, N. Hidayat, and R. K. Dewi, "Implementasi Metode K-Nearest Neighbor Untuk Mendiagnosis Penyakit Tanaman Bawang Merah," J. Pengemb. 
Teknol. Inf. dan Ilmu Komput., vol. 5, no. 1, pp. 11-16, 2021.

[7] M. Reza Noviansyah, T. Rismawan, and D. Marisa Midyanti, "Penerapan Data Mining Menggunakan Metode K-Nearest Neighbor Untuk Klasifikasi Indeks Cuaca Kebakaran Berdasarkan Data Aws (Automatic Weather Station) (Studi Kasus: Kabupaten Kubu Raya)," J. Coding, Sist. Komput. Untan, vol. 06, no. 2, pp. 48-56, 2018, [Online]. Available:

http://jurnal.untan.ac.id/index.php/jcskommi pa/article/view/26672.

[8] M. Rivki and A. M. Bachtiar, "Implementasi Algoritma K-Nearest Neighbor Dalam Pengklasifikasian Follower Twitter Yang Menggunakan Bahasa Indonesia," J. Sist. Inf., vol. 13, no. 1, p. 31, 2017, doi: 10.21609/jsi.v13i1.500.

[9] M. Saiful and Syamsuddin, "Implementasi Algoritma Naive Bayes Untuk Memprediksi Predikat Ketuntasan Belajar Siswa Pasca Pandemi Covid 19," J. Inform. dan Teknol., vol. 4, no. 1, pp. 96-104, 2021.

[10] R. A. Arnomo, W. L. Y. Saptomo, and P. Harsadi, "Implementasi Algoritma K-Nearest Neighbor Untuk Identifikasi Kualitas Air (Studi Kasus: Pdam Kota Surakarta)," J. Teknol. Inf. dan Komun., vol. 6, no. 1, 2018, doi: 10.30646/tikomsin.v6i1.345.

[11] R. R. Rahayu, "Mplementasi algoritma c4.5 untuk menentukan aturan rekomendasi calon penerima beasiswa," INFOKOM, vol. 7, no. 2, pp. 37-43, 2019, [Online]. Available:

http://journal.piksi.ac.id/index.php/INFOKO M/article/view/163.

[12] S. Sanjaya, M. L. Pura, S. K. Gusti, F. Yanto, and F. Syafria, "K-Nearest Neighbor for Classification of Tomato Maturity Level Based on Hue, Saturation, and Value Colors," Indones. J. Artif. Intell. Data Min., vol. 2, no. 2, p. 101, 2019, doi: 10.24014/ijaidm.v2i2.7975.
[13] Yahya and W. Puspita Hidayanti, "Penerapan Algoritma K-Nearest Neighbor Untuk Klasifikasi Efektivitas Penjualan Vape (Rokok Elektrik) pada 'Lombok Vape On,"' Infotek J. Inform. dan Teknol., vol. 3, no. 2, pp. 104-114, 2020, doi: 10.29408/jit.v3i2.2279.

[14] B. Liu, Web Data Mining Exploring Hyperlinks, Content, and Usage Data, Second. Springer London, 2011.

[15] J. Han, M. Kamber, and J. Pei, Data Mining Concepts and Techniques, Third. Morgan Kaufman Publishers, 2012.

[16] M. Saiful and S. Aris, "Penerapan Sistem Informasi Tracer Study untuk Mengetahui Tingkat Kontribusi Perguruan Tinggi dengan Kompetensi Lulusan ( Studi Kasus Fakultas Teknik Universitas Hamzanwadi )," J. Inform. dan Teknol., vol. 2, no. 1, pp. 43-52, 2019. 